\title{
Post mortem changes: challenges in drug analysis in the diagnosis of deaths from intoxication
}

\author{
Marina Camargo Galera ${ }^{a}$ and Luciana Grazziotin Rossato-Grando*b \\ ${ }^{a}$ Instituto de Ciências Biológicas, Curso de Farmácia, Universidade de Passo Fundo, Passo Fundo, Brazil; ${ }^{b}$ Programa \\ de Pós-Graduação em Bioexperimentação, Universidade de Passo Fundo, Passo Fundo, Brazil \\ *Corresponding author: luciana.r.grando@gmail.com
}

\begin{abstract}
In forensic toxicology, alternative matrices and sampling sites are required for a correlation of antemortem and postmortem concentrations with the least possible error. Postmortem redistribution phenomena and biochemical changes inherent to these processes are possible, and represent interferences in these analyses. This study aimed to perform a bibliographic review analyzing different forensic matrices and its interferences in analytical toxicology. We observed that for quantitative analyses the preferred matrix is blood from peripheral vessels, and when it is not available, vitreous humor is a great specimen for choice.
\end{abstract}

Keywords: Postmortem redistribution, toxicological analyses, sampling site, vitreous humor, forensic toxicology.

https://doi.org/10.22456/2527-2616.111711

\section{Introduction}

Forensic toxicology is very important for the materialization of a crime, being applied in fatal cases where the presence of a toxic agent is suspected. So, this science aims to detect postmortem concentrations of xenobiotics such as drugs and interpreting the results found, correlating them as causative or contributor agents of death $(1,3)$.

After death, the body undergoes changes, which affect the matrices commonly used in antemortem analyses. For example, some of these changes involve bacterial contamination and postmortem redistribution, which ultimately ends up interfering with the analyses and interpretation of xenobiotic concentrations of forensic interest $(4,5)$. Thus, matrices that are protected of internal and external factors and consequently suffer less interference have been researched for a more accurate diagnosis $(4,6)$.

The present review aimed to analyze different matrices, as well as the interpretation of the greatest postmortem interferences suffered for specimens, the situations they must be used and also the qualities that make them eligible as the matrix of choice for tests in forensic toxicology.

\section{Materials and Methods}

A literature review was conducted regarding the changes that occur in postmortem kinetics of drugs. The search was performed in books, scientific documents and Pubmed database, with time span of the last ten years. The following keywords were used for the bibliographic survey: "biological matrices", forensic toxicology", "forensic analysis AND redistribution". We selected the articles available in full and free of charge. Articles that were not related to forensic toxicological analyses or postmortem redistribution were excluded.

\section{Results and Discussion}

\section{Post mortem redistribution}

One of the main challenges in forensic analysis is postmortem redistribution. Several factors influence the redistribution of a xenobiotic. The characteristics of the substance influences the proportion of redistribution that it may undergo, for instance, analytes that have high volume of distribution $(\mathrm{Vd})$, that are lipophilic and present alkaline properties tend to suffer more this phenomenon $(1,2,9,10)$. Passive diffusion of analytes from reservoir organs to other tissues and blood occurs. Cellular autolysis also affects the arrangement of substances, since it acidifies the $\mathrm{pH}$ of the medium, resulting in the accumulation of alkaline xenobiotics $(9,11)$. These factors affect central matrices in a greater proportion due to their proximity to thoracoabdominal organs (1). It is also important to consider the characteristics of the individual as age, body fat, and nutritional status, since they affect postmortem redistribution as well (2).

Regarding blood analyses, the place from where it is collected is of great importance. Many studies show that peripheral blood suffers less postmortem redistribution than central blood, such as cardiac or hepatic. Therefore, authors suggest peripheral blood as a better choice for postmortem analysis $(1,2,8)$. This fact is demonstrated in a study with the compound olanzapine, an antipsychotic drug. The elevation of its concentrations in the femoral vein corresponded to the increase in blood, while in the hepatic and pulmonary vein the increase was 2.5 to 3.3 times higher than in the blood, showing an increase of up to seven times after death. This fact can be explained by the lipophilic nature of the substance and its elevated $\mathrm{Vd}$, making it subject to redistribution (6).

Another possibility is to use blood derived from the popliteal vein, which is less used. It was observed that the concentrations of diazepam, methadone and morphine found in blood samples from the popliteal vein are lower than the central and even femoral vein. Hence, it can be said 
that samples analyzed in blood from the popliteal vein are less subject to postmortem redistribution than samples of femoral blood. This can be justified by its anatomical position further away from central organs (1).

One way to estimate postmortem redistribution of compounds is by calculating the $\mathrm{C} / \mathrm{P}$ ratio, i.e., the ratio of the center to the periphery (1). The higher this proportion, the greater the postmortem redistribution suffered by the xenobiotic. A proportion less than or equal to 1 is consistent with an analyte with low or non-existent redistribution $(1,2)$. However, this proportion is not always reliable to estimate the postmortem redistribution, since discrepancies may occur in cases of attempted cardiopulmonary resuscitation or incomplete distribution events of the substance. In addition, there are compounds that theoretically undergo a small or zero postmortem redistribution, however, they present $\mathrm{C} / \mathrm{P}$ ratios greater than 1 (1).

Most neutral or acidic drugs have a blood/plasma ratio less than or equal to 1 , and medicines with higher plasma binding show a lower redistribution. For alkaline drugs, this ratio is greater than 1, probably due to postmortem redistribution (8).

\section{Postmortem matrices}

Table 1 contains the main matrices employed in postmortem analysis and the advantages/disadvantages of each.

Table 1 - Advantages and disadvantages of the postmortem matrices.

\begin{tabular}{ccll}
\hline Reference & Matrix & \multicolumn{1}{c}{ Advantages } & Disadvantages \\
\hline (4) & Bile & $\begin{array}{l}\text { Easy collection during autopsy. Matrix with higher } \\
\text { concentrations than blood. High value for } \\
\text { screening of intoxications. }\end{array}$ & $\begin{array}{l}\text { Matrix effect, usually the sample must be diluted to } \\
\text { be correlated with blood. Development of specific } \\
\text { methods for biliary detection. Less knowledge about } \\
\text { biliary excretion, affinity of compounds for } \\
\text { hepatocytes and membrane transporters for the } \\
\text { selection of compounds that could be commonly } \\
\text { analyzed in bile. }\end{array}$ \\
\hline (3) & $\begin{array}{l}\text { Vitreous } \\
\text { humor }\end{array}$ & $\begin{array}{l}\text { Less vulnerable to bacterial contamination and } \\
\text { enzyme degradation. Considered a high sensitivity } \\
\text { matrix for being "clean". Easy to obtain. }\end{array}$ & $\begin{array}{l}\text { Quatitave interpretation, since blood/vitreous } \\
\text { humpor concentrations do not correlate for all } \\
\text { compounds. Preparation of the sample is required due } \\
\text { to its viscosity. }\end{array}$
\end{tabular}

\begin{tabular}{|c|c|c|c|}
\hline (5) & $\begin{array}{l}\text { Blood, serum } \\
\text { or plasma, } \\
\text { vitreous humor }\end{array}$ & $\begin{array}{l}\text { Frozen/refrigerated serum or plasma samples can } \\
\text { be used for immunoassay testing. }\end{array}$ & $\begin{array}{l}\text { Blood is not a good matrix for insulin analysis as it is } \\
\text { subject to putrefaction, hemolysis and coagulation. }\end{array}$ \\
\hline (1) & $\begin{array}{l}\text { Blood } \\
\text { collected in } \\
\text { different } \\
\text { vessels }\end{array}$ & $\begin{array}{l}\text { The blood collected from the popliteal vein seems } \\
\text { to be less susceptible to redistribution, since it is } \\
\text { further away from the thoracic region, where } \\
\text { changes such as cellular autolysis begins. The } \\
\text { concentrations of xenobiotics found are lower than } \\
\text { in the central region. }\end{array}$ & Popliteal blood is not commonly used. \\
\hline (2) & $\begin{array}{l}\text { Cardiac and } \\
\text { iliac blood }\end{array}$ & $\begin{array}{l}\text { The use of blood from one central and other } \\
\text { peripheral anatomical site was essential for the } \\
\text { estimation of redistribution. }\end{array}$ & $\begin{array}{l}\text { Redistribution was moderate, contrary to the estimate } \\
\text { based on cannabinoids, since its structure } \\
\text { characteristics tend to increase postmortem } \\
\text { redistribution. }\end{array}$ \\
\hline (6) & $\begin{array}{l}\text { Femoral, } \\
\text { pulmonary and } \\
\text { hepatic blood }\end{array}$ & $\begin{array}{l}\text { The blood collected in the femoral vein seems to } \\
\text { be the most indicated for correlation of peripheral } \\
\text { olanzapine concentrations. }\end{array}$ & $\begin{array}{l}\text { Blood collected from the pulmonary and hepatic vein } \\
\text { showed higher concentrations of xenobiotics. }\end{array}$ \\
\hline (7) & $\begin{array}{l}\text { Blood and } \\
\text { brain }\end{array}$ & $\begin{array}{l}\text { Blood and brain concentrations of JWH-018 and } \\
\text { JWH-073, cannabinomimetic substances may } \\
\text { initially increase to easily detectable values. }\end{array}$ & $\begin{array}{l}\text { Concentrations decrease dramatically after a few } \\
\text { hours and may become undetectable after } 24 \text { hours. }\end{array}$ \\
\hline (8) & Femoral blood & $\begin{array}{l}\text { Femoral blood is less subject to postmortem } \\
\text { redistribution, data analysis supports the } \\
\text { interpretation of these results. If the concentration } \\
\text { of therapeutic range was used, the interpretation } \\
\text { would be wrong in most cases. }\end{array}$ & \\
\hline
\end{tabular}


As the bile duct helps in the elimination of xenobiotics, it represents a good matrix for analysis, since it is easy to sample and tends to present high concentrations of substances that are excreted by bile, such as 11-Nor-9carboxi-THC (THC-COOH), 11-hydroxy-THC (11OHTHC), $\Delta$-9-tetrahydrocannabinol (THC) metabolites. Further, some researched analytes can be detected only in bile and not in the blood. Another quality is the unfavorable environment that bile presents for the proliferation of microorganisms, being less subject to contamination. And it is also a matrix indicated for drugs with short half-life when there is a longer survival period, which is characterized by the time between the ingestion and death of the individual (4). However, there is the possibility that some substances that are present in blood are not detected in bile, especially in cases of rapid death. Xenobiotics are subject to postmortem redistribution, because the gallbladder is located near other abdominal organs. Bile has not been a thoroughly studied matrix, so its concentrations should not be extrapolated to blood concentrations, for this, new methods must be developed (4).

Vitreous humor is referred to as an interesting alternative matrix and can be used for xenobiotic detection and for estimation of the postmortem interval, which can be estimated by the decrease in potassium $(11,12)$. It is easily sampled, presents less susceptibility to bacterial contamination and few interfering factors, and has a smaller postmortem redistribution, thus generating greater stability. This is due to its location away from abdominal organs, little vascularization and protection by the eyeball. Despite these advantages, ocular tissue can be a site of accumulation of xenobiotics, which are able to be redistributed to this matrix after death (3). However, blood and vitreous humor concentrations cannot be correlated for all substances, such as morphine and diazepam, which have higher concentrations in vitreous humor. Survival time, ophthalmic pathologies drug interactions and postmortem interval also interfere in this correlation. So, the extrapolation from vitreous humor to blood concentrations must take account all these factors (3).

Another interesting application is the estimated survival time, based on the ratio blood/vitreous humor concentration through the time of distribution from blood to vitreous humor, since soon after ingestion this ratio is higher (3). Vitreous humor use is also relevant for dosing postmortem ethanol, which is subject to neoformation by action of bacteria and therefore often the concentrations found postmortem do not agree with the antemortem. In most cases, ethanol postmortem concentrations are higher than antemortem, consequently the analysis of vitreous humor is indicated due to its lower susceptibility to bacterial activity (13).

So, blood, plasma, serum and vitreous humor are matrices that can be used to quantify xenobiotics in confirmatory analyses, performing the correlation of its concentrations with that which was administered in life. Other matrices, such as organs, can be used in cases where blood is not available. Usually when the cadaver is found after a longer post mortem interval, as exemplified in the table below (Table 2). These matrices are used for the screening of substances, since, due to the various changes suffered by the cadaver, their concentrations do not correspond with antemortem state (15):

Table 2 - Cases for the use of alternative matrices

\begin{tabular}{l|l}
\hline Matrix & When to use \\
\hline Liver & $\begin{array}{l}\text { Perform liver tissue sampling whenever } \\
\text { possible, as many substances undergo } \\
\text { hepatic metabolization (15-17). }\end{array}$ \\
\hline $\begin{array}{l}\text { Gastric content: } \\
\text { gastric aspirate }\end{array}$ & $\begin{array}{l}\text { Useful in cases of oral intoxication and for } \\
\text { screening purposes, since they can be } \\
\text { identified in the stomach before being } \\
\text { metabolized (15,18,19). }\end{array}$ \\
\hline Brain & $\begin{array}{l}\text { Interesting matrix to interpret the toxicity } \\
\text { of substances in the central nervous system } \\
\text { (15,20,21). }\end{array}$ \\
\hline Spleen & $\begin{array}{l}\text { Used in cases of poisoning by cyanide and } \\
\text { carbon monoxide, substances that } \\
\text { accumulate in erythrocytes (15,17). }\end{array}$ \\
\hline Lung & $\begin{array}{l}\text { Used when the toxic agent is a volatile } \\
\text { substance (15,22,23). }\end{array}$ \\
\hline Bidney & $\begin{array}{l}\text { Useful matrix considering its role as an } \\
\text { excretory organ. Heavy metals tend to } \\
\text { accumulate in this matric (15-17). }\end{array}$ \\
\hline Urine & $\begin{array}{l}\text { Used in cases where the cadaver is in the } \\
\text { process of deselecting. Important role in } \\
\text { metal analysis (15,24). }\end{array}$ \\
\hline Hair and nail & $\begin{array}{l}\text { Not common in post mortem analyses. } \\
\text { Generally, in cases of overdose the } \\
\text { survival time is not enough to excrete the } \\
\text { toxicant and low concentrations of the } \\
\text { toxic agent is found in urine (18,21,25). }\end{array}$ \\
\hline $\begin{array}{l}\text { These keratinized matrices are not useful } \\
\text { for the analysis of acute intoxication, but } \\
\text { allow retrospective evidence (21,26-28). }\end{array}$ \\
\hline
\end{tabular}

\section{Conclusions}

The location from which the blood sample is collected can greatly influence the quality of forensic toxicological analysis, since the central blood vessels are more susceptible to postmortem redistribution. The femoral vein is generally preferred for blood sampling; however, studies have shown that the popliteal vein tends to undergo even less redistribution than the femoral vein, what makes it possible to correlate the concentrations of analytes found in popliteal vein more closely with the concentration ingested before death when compared to other anatomical sites. Among the alternative matrices analyzed, vitreous humor stands out as it is less subject to cadaveric transformations and external interferences.

\section{Conflict of interest}

The authors declare no conflicts of interest.

\section{References}

1.Launiainen T, Ojanperä I. Drug concentrations in postmortem femoral blood compared with therapeutic concentrations in plasma. Drug Test Anal. 2014;6(4):30816. 
2.Carvalho virgínia M, Fontes LR, Lima IVi, Fuzinato DV. Toxicologia post mortem. In: Oga S, Camargo MM de A, Batistuzzo JA de O, editors. Fundamentos de toxicologia. São Paulo: Editora Atheneu; 2014. p. 645 a 656.

3.Chasin A da M, Lima IV. Toxicologia Forense. In: Oga S, Camargo MM de A, Batistuzzo JA de O, editors. Fundamentos de toxicologia. 4a edição. São Paulo: Editora Atheneu; 2014. p. 639 a 644.

4.Lemaire E, Schmidt C, Dubois N, Denooz R, Charlier C, Boxho P. Site-, Technique-, and Time-Related Aspects of the Postmortem Redistribution of Diazepam, Methadone, Morphine, and their Metabolites: Interest of Popliteal Vein Blood Sampling. J Forensic Sci. 2017;62(6):1559-74.

5.Holland MG, Schwope DM, Stoppacher R, Gillen SB, Huestis MA. Postmortem redistribution of $\Delta 9$ tetrahydrocannabinol (THC), 11- hydroxy-THC (11-OHTHC), and 11-nor-9-carboxy-THC (THCCOOH). Bone. 2011;23(1):247-51.

6.Bévalot F, Cartiser N, Bottinelli C, Fanton L, Guitton J. Vitreous humor analysis for the detection of xenobiotics in forensic toxicology: a review. Forensic Toxicol. 2016;34(1):12-40.

7.Remião F, Bastos M de L. Disposição dos Xenobióticos nos Sistemas Biológicos: Absorção, Distribuição, Metabolismo, Excreção e Transporte (ADMET). In: DinisOliveira RJ, Carvalho FD, Bastos M de L, editors. Toxicologia Forense. Lisboa: Pactor; 2015. p. 9 a 58.

8.Sastre C, Bartoli C, Baillif-Couniou V, Leonetti G, Pelissier-Alicot A-L. Post Mortem Redistribution of Drugs: Current State of Knowledge. Current Pharmaceutical Design [Internet]. 2017;23(36):5530-41. Available from: http://www.eurekaselect.com/node/153547/article

9.Johnson JT, Everly AG, Kpakima FEF, Detke HC. Postmortem redistribution of olanzapine following intramuscular administration of olanzapine pamoate in dogs. Forensic Sci Int. 2015;257:353-8.

10.Bévalot F, Cartiser N, Bottinelli C, Guitton J, Fanton L. State of the art in bile analysis in forensic toxicology. Forensic Sci Int. 2016;259:133-54.

11.Labay LM, Bitting CP, Legg KM, Logan BK. The Determination of Insulin Overdose in Postmortem Investigations. Acad Forensic Pathol. 2016;6(2):174-83.

12.Poklis JL, Amira D, Wise LE, Wiebelhaus JM, Haggerty BJ, Poklis A. Detection and disposition of JWH-018 and JWH-073 in mice after exposure to "Magic Gold" smoke. Forensic Sci Int [Internet]. 2012 Jul 10 [cited 2020 Sep 28];220(1-3):91-6. Available from: https://pubmed.ncbi.nlm.nih.gov/22405481/

13.Pigaiani N, Bertaso A, De Palo EF, Bortolotti F, Tagliaro F. Vitreous humor endogenous compounds analysis for post-mortem forensic investigation. Forensic Sci Int [Internet]. 2020 May 1 [cited 2020 Apr 29];310. Available from:

https://www.sciencedirect.com/science/article/pii/S037907 3820300979?via\%3Dihub

14.Savini F, Tartaglia A, Coccia L, Palestini D, D’Ovidio C, Grazia U De, et al. Ethanol Determination in PostMortem Samples: Correlation between Blood and Vitreous Humor Concentration. Molecules. 2020;25(12):1-9.
15.Dinis-Oliveira RJ, Carvalho FD, Duarte JA, Magalhães T. Recomendações Gerais para Colheita de Amostras Biológicas em Toxicologia Forense. In: Dinis-Oliveira RJ, Carvalho FD, Bastos M de L, editors. Toxicologia Forense. Lisboa: Pactor; 2015. p. 103 a 108.

16.Hořínková J, Kozlík P, Křížek T, Michaličková D, Šíma M, Slanař O. Post-mortem Redistribution of Alprazolam in Rats. Prague Med Rep [Internet]. 2020 [cited 2021 Apr 27];121(4):244-53. Available from: https://doi.org/10.14712/23362936.2020.21

17.Diab AM, Salem RM, Abeer EKMS, Ali GIE, ElHabashi N. Experimental ochratoxicosis A in Nile tilapia and its amelioration by some feed additives. Int J Vet Sci Med [Internet]. 2018 Dec 1 [cited 2021 Apr 29];6(2):149$58 . \quad$ Available from: https://doi.org/10.1016/j.ijvsm.2018.09.004

18.Proença P, Teixeira H, Pinheiro J, Monsanto P V., Vieira DN. Fatal intoxication with tianeptine (Stablon $\left.{ }^{\circledR}\right)$. Forensic Sci Int [Internet]. 2007 Aug 6 [cited 2021 Apr 27];170(23):200-3. Available from: https://core.ac.uk/reader/19123183?utm_source=linkout 19.Fagiola M, Hahn T, Avella J. Evaluation of Acetylfentanyl Following Suspected Heroin Overdose When Complicated by the Presence of Toxic Fentanyl and Alprazolam Concentrations. Acad Forensic Pathol [Internet]. 2019 Sep 1 [cited 2021 May 1];9(3-4):191-9. Available https://pubmed.ncbi.nlm.nih.gov/32110254/

20.Chun H-J, Poklis JL, Poklis A, Wolf CE. Development and Validation of a Method for Alcohol Analysis in Brain Tissue by Headspace Gas Chromatography with Flame Ionization Detector. $\mathrm{J}$ Anal Toxicol [Internet]. 2016;40:653-8. Available from: https://academic.oup.com/jat/article/40/8/653/2450720

21.Busardò FP, Jones AW. Interpreting $\gamma$-hydroxybutyrate concentrations for clinical and forensic purposes. Clinical Toxicology. 2019 Mar 4;57(3):149-63.

22.Antonini JM, Roberts JR, Schwegler-Berry D, Mercer RR. Comparative microscopic study of human and rat lungs after overexposure to welding fume. Ann Occup Hyg. 2013;57(9):1167-79.

23.Bottoni E, Fiore PA, Cappelletti S, Y Petrasso PE, Straccamore M, Marco Straccamore D. Volatile substance related deaths: a simple and safe autopsy procedure for sampling and preserving aliphatic hydrocarbons. Clin Ter. 2018;169(5):231-4.

24.Figueiredo FAT de. Determinação de chumbo e massa de tíbias de ratos Wistar machos expostos a $30 \mathrm{mg} / \mathrm{l} \mathrm{de}$ chumbo na água de beber desde o período intrauterino até a idade de 28 e 60 dias [Internet]. [Ribeirão Preto]: Biblioteca Digital de Teses e Dissertações da Universidade de São Paulo; 2012 [cited 2021 May 2]. Available from: http://www.teses.usp.br/teses/disponiveis/58/58137/tde07022013-114750/

25.Boumrah Y, Gicquel T, Hugbart C, Baert A, Morel I, Bouvet R. Suicide by self-injection of chlormequat trademark C5SUN®. Forensic Sci Int [Internet]. 2016 Jun 1 [cited 2021 May 1];263:9-13. Available from: https://pubmed.ncbi.nlm.nih.gov/27020619/ 
26.Mueller F, Bogdal C, Pfeiffer B, Andrello L, Ceschi A, Thomas A, et al. Isotonitazene: Fatal intoxication in three cases involving this unreported novel psychoactive substance in Switzerland. Forensic Sci Int [Internet]. 2021 Mar 1 [cited 2021 May 1];320. Available from: http://creativecommons.org/licenses/by/4.0/

27.Borgo AP. Cocaine analysis post-mortem in hair using LC-MS/MS technique. [Campinas]: Universidade Estadual de Campinas; 2016.

28.Loss CG. Development and validation of a method for quantification of cocaine and its metabolites in nails by LCMS/MS (Toxicological profile post-mortem of nails : a tool in criminal investigation). [Campinas]: UNICAMP; 2015. 